\title{
Expression of endoglin (CDI05) in cervical cancer
}

\author{
HJ Zijlmans ${ }^{1,2}$, GJ Fleuren', S Hazelbag' ${ }^{2}$ CF Sier ${ }^{3}$, EJ Dreef', GG Kenter ${ }^{4}$ and A Gorter,,I \\ 'Department of Pathology, Leiden University Medical Centre, 2300 RC Leiden, The Netherlands; ${ }^{2}$ Department of Obstetrics and Gynaecology, Medical \\ Centre Haaglanden, 2501 CK The Hague, The Netherlands; ${ }^{3}$ Department of Gastroenterology and Hepatology, Leiden University Medical Centre, 2300 \\ RC Leiden, The Netherlands; ${ }^{4}$ Department of Gynaecology, Leiden University Medical Centre, 2300 RC Leiden, The Netherlands
}

In this study, we have investigated the role of endoglin (CDI05), a regulator of transforming growth factor (TGF)- $\beta_{\text {। }}$ signalling on endothelial cells, basic fibroblast growth factor (bFGF) and vascular endothelial growth factor-A (VEGF-A) in cervical cancer. We have measured the number and determined the location of both newly formed (CDI05-positive) and the overall number of (CD3 I-positive) blood vessels, and bFGF and VEGF-A expression using immunohistochemistry in 30 cervical carcinoma specimens. Vascular endothelial growth factor-A mRNA expression was determined using RNA-in situ hybridisation. CD I 05- and CD3 I-positive vessels and bFGF- and VEGF-A-positive cells were predominantly present in the stroma. The presence of CDI05- and CD31-positive vessels in the stroma did neither correlate with the number of VEGF-A-positive cells nor the number of bFGF-positive cells. However, the number of CDI05- and CD3I-positive vessels was associated with the expression of VEGF-A mRNA in the epithelial cell clusters $(P=0.013$ and $P=0.005$, respectively). The presence of CDI05-positive and CD3I-positive vessels was associated with the expression of $\alpha \vee \beta 6$ (a TGF- $\beta_{1}$ activator; $P=0.013$ and $P=0.006$, respectively). Clinically, the number of CDI05positive vessels associated with the number of lymph node metastasis $(P<0.00 \mathrm{I})$. Furthermore, the presence of $C D I 05-p o s i t i v e$ vessels within the epithelial cell clusters associated with poor disease-free survival $(P=0.007)$.

British Journal of Cancer (2009) 100, 1617- 1626. doi:10.1038/sj.bjc.6605009 www.bjcancer.com

Published online 7 April 2009

(C) 2009 Cancer Research UK

Keywords: cervical cancer; angiogenesis; cytokines

Cervical cancer is the second most common cancer among women worldwide and one of the main causes of cancer-related death in the developing countries (Parkin et al, 2005). The prognosis of patients is, amongst others, dependent on tumour size, lymph node metastasis, capillary lymphatic space involvement, infiltration of the tumour in the cervix, infiltration of the tumour in the parametria and absence of tumour at the surgical margins (Hellebrekers et al, 1999). Cervical tumours are composed of malignant epithelial cells, tumour stroma, comprising the tumour vasculature, and an inflammatory infiltrate. A significant association between tumour vascular density and poor clinical outcome has been reported (Cooper et al, 1998, 1999; Pilch et al, 2001a). Growth and metastatic capacity of solid tumours depend on tumour vascular density and angiogenesis (Pilch et al, 2001b; Bremnes et al, 2006). Hypoxia in the centre of the epithelial cancer cell nests is thought to be a driving force behind angiogenesis (Byrne et al, 2005).

Tumours promote angiogenesis by secreting factors, like vascular endothelial growth factor-A (VEGF-A), basic fibroblast growth factor (bFGF) (Salgado et al, 2004; Bremnes et al, 2006) and transforming growth factor (TGF)- $\beta_{1}$. In addition, the presence of an inflammatory infiltrate is thought to be of great importance in neovascularisation (Condeelis and Pollard, 2006).

A marker for angiogenesis is endoglin (Dallas et al, 2008). Endoglin, designated CD105, is a $90 \mathrm{kDa}$ (under reducing

*Correspondence: Dr A Gorter; E-mail: A.Gorter@lumc.nl

Received 7 October 2008; revised 19 January 2009; accepted 5 March 2009; published online 7 April 2009 conditions) TGF- $\beta$ type III auxiliary receptor involved in the regulation of TGF- $\beta_{1}$ signalling in endothelial cells. Overexpression of CD105 inhibits TGF- $\beta$ /ALK5 signalling and TGF- $\beta$-induced growth inhibition, whereas knockdown of CD105 inhibits TGF- $\beta$ / ALK1 signalling and endothelial cell proliferation (ten Dijke et al, 2008). CD105 is required for efficient TGF- $\beta / A L K 1$ signalling on proliferating endothelial cells (ten Dijke and Arthur, 2007). In contrast to CD31, which is expressed on blood vessels both in normal tissue and in malignant lesions, endoglin is found predominantly on peritumoural and intratumoural blood vessels. The expression of CD105 on tumour-associated blood vessels makes CD105 a potential molecular target for therapy (Dallas et al, 2008).

Transforming growth factor- $\beta_{1}$ plays a dual role in cancer: early in tumour development it acts as a tumour suppressor, inhibiting epithelial cell proliferation, whereas late in cancer development it suppresses the activity of the immune system and induces regulatory $\mathrm{T}$ cells (Elliott and Blobe, 2005). Transforming growth factor- $\beta_{1}$ also plays an important role in angiogenesis by promoting proliferation and migration of endothelial cells at low TGF- $\beta_{1}$ concentrations, whereas high concentrations lead to cytostasis and promote vessel maturation (ten Dijke and Arthur, 2007). Furthermore, TGF- $\beta_{1}$ is known to induce VEGF expression (McMahon et al, 2006). Earlier we have reported on the expression of TGF- $\beta_{1}$, plasminogen activator inhibitor (PAI)-1 and fibronectin (both target gene products of TGF- $\beta_{1}$ ) and $\alpha \mathrm{v} \beta 6$ (activator of TGF- $\beta_{1}$ ) in cervical carcinoma (Hazelbag et al, 2002, 2004, 2007).

In this study, we have expanded our observations on the role of TGF- $\beta_{1}$ in cervical cancer by measuring the number and 
determining the location of CD105-positive blood vessels. To further analyse the role of endoglin as a TGF- $\beta_{1}$-associated regulatory molecule in the angiogenic process, we have compared the number and location of the newly formed CD105-positive vessels with the number and location of CD31-positive blood vessels (total number of blood vessels) and we have measured the expression of the pro-angiogenic factors, VEGF-A and bFGF. Finally, the clinico-pathological relevance of CD105 in cervical carcinoma was assessed.

\section{MATERIALS AND METHODS}

\section{Patient material}

A total of 30 patients treated with radical abdominal hysterectomy and bilateral pelvic lymph node dissection for uterine cervical cancer (Wertheim's procedure) was included in this study. According to the International Federation of Gynaecology and Obstetrics (FIGO) staging system for cervical carcinoma (Moore, 2006) 10 patients were selected for a high FIGO stage (at least FIGO IIA), whereas the other 20 patients were randomly selected patients with a FIGO stage IB. Patients had received no therapy before surgery. Treatment occurred between 1985 and 1994. Tissues had been fixed routinely in $10 \% \mathrm{v} / \mathrm{v}$ formalin and embedded in paraffin. Samples were used according to the guidelines of the

Table I Summary of clinico-pathological features of patients and tumours

\begin{tabular}{|c|c|c|}
\hline Characteristics of patients and tumours & Outcome & $\mathbf{N}^{\mathrm{a}}$ \\
\hline Age & $\begin{array}{l}45 \text { (mean) } \\
29-72 \text { (range) }\end{array}$ & 30 \\
\hline FIGO stage & $\begin{array}{l}\leqslant 1 B \\
\geqslant \| A\end{array}$ & $\begin{array}{l}20 \\
10\end{array}$ \\
\hline Lymph node metastasis & $\begin{array}{l}\text { No } \\
\text { Yes }\end{array}$ & $\begin{array}{l}16 \\
14\end{array}$ \\
\hline Tumour size & $\begin{array}{l}<40 \mathrm{~mm} \\
\geqslant 40 \mathrm{~mm}\end{array}$ & $\begin{array}{l}16 \\
12\end{array}$ \\
\hline Infiltration depth ${ }^{b}$ & $\begin{array}{l}<15 \mathrm{~mm} \\
\geqslant 15 \mathrm{~mm}\end{array}$ & $\begin{array}{c}15 \\
9\end{array}$ \\
\hline Vascular space involvement & $\begin{array}{l}\text { No } \\
\text { Yes }\end{array}$ & $\begin{array}{l}10 \\
20\end{array}$ \\
\hline Parametrial invasion & $\begin{array}{l}\text { No } \\
\text { Yes }\end{array}$ & $\begin{array}{l}20 \\
10\end{array}$ \\
\hline HPV status ${ }^{b}$ & $\begin{array}{l}16,18 \\
\text { Other }\end{array}$ & $\begin{array}{c}19 \\
6\end{array}$ \\
\hline Histology & $\begin{array}{l}\text { Squamous } \\
\text { Adenosquamous } \\
\text { Adeno }\end{array}$ & $\begin{array}{c}25 \\
4 \\
1\end{array}$ \\
\hline
\end{tabular}

$\mathrm{FIGO}=$ Federation of Gynaecology and Obstetrics. ${ }^{a} \mathrm{~N}=$ number of patients/cervical carcinomas. ${ }^{b}$ Cases missing.
Ethical Committee of the Leiden University Medical Centre. The patient characteristics are shown in Table 1.

\section{Immunohistochemistry}

Immunohistochemical analysis was performed on $3 \mu \mathrm{m}$ paraffin sections, mounted on aminopropylethoxysilane-coated slides. Sections were deparaffinised, rehydrated and treated with $0.3 \%$ $\mathrm{v} / \mathrm{v}_{2} \mathrm{O}_{2}$ in methanol for 20 min to block endogenous peroxidase activity. Antigen retrieval was performed, if necessary, and sections were rinsed in phosphate-buffered saline (PBS) followed by an incubation with $1 \% \mathrm{w} / \mathrm{v}$ bovine serum albumin (BSA) in PBS. Subsequently, sections were stained for CD68 (Zijlmans et al, 2006), $\alpha v \beta 6$ (Hazelbag et al, 2007), fibronectin (Hazelbag et al, 2002), VEGF-A, bFGF, matrix metalloproteinase (MMP)-2 (Sier et al, 2006), CD31 and CD105 (see Table 2 for characteristics of the primary antibodies). All antibodies were diluted in $1 \%$ BSA in PBS. In case of CD68, $\alpha v \beta 6$, bFGF, MMP-2 and CD31 (a biotinylated secondary rabbit anti-mouse antibody) was used (1:200, DAKO, Glostrup, Denmark). For VEGF-A, biotinylated swine anti-rabbit antibody, and for fibronectin, biotinylated rabbit anti-goat antibody was used (both $1: 400$, DAKO). All slides were subsequently incubated with a biotinylated horseradish peroxidase (HRP) - streptavidin complex $(1: 100, \mathrm{DAKO})$ and immune complexes were visualised with diaminobenzidine. Staining for CD105 was performed with a CSA Detection System (DAKO), according to the manufacturer's protocol. Negative controls consisting of tissue sections where the primary antibody was replaced by an (irrelevant) antibody (DAKO) directed against the same isotype as the primary antibody.

\section{Probe preparation and RNA-in situ hybridisation}

Oligonucleotide primers were chosen on the basis of known sequences (5'-GCCTCCGAAACCATGAACTTT-3' (sense) and $5^{\prime}$-CCGCATAATCTGCATGGTGAT-3' (antisense)) (GenBank accession number GI065522.1).

Cervical carcinoma sections were stained for VEGF-A mRNA as described earlier (Zijlmans et al, 2006). In short: $3 \mu \mathrm{m}$ paraffin sections were pre-treated and hybridised with $100 \mathrm{ng} \mathrm{ml}^{-1}$ DIGlabelled RNA probe diluted in hybridisation mixture containing $0.3 \mathrm{M} \mathrm{NaCl}$ and $0.03 \mathrm{M}$ saline-sodium citrate (SSC). Hybridisation was allowed for $16 \mathrm{~h}$ at $50^{\circ} \mathrm{C}$ in a humidified chamber. Slides were washed for $30 \mathrm{~min}$ in $50 \% \mathrm{v} / \mathrm{v}$ formamide $/ 2 \times$ SSC at $42^{\circ} \mathrm{C}$, followed by $45 \mathrm{~min}$ in $0.1 \times$ SSC with $20 \mathrm{~mm} \beta$-mercaptoethanol at $50^{\circ} \mathrm{C}$ and $30 \mathrm{~min}$ with $2 \mathrm{U} \mathrm{ml}^{-1}$ ribonuclease (RNase) T1 (Roche Diagnostics GmbH, Mannheim, Germany) in $2 \times$ SSC, 1 mM EDTA at $37^{\circ} \mathrm{C}$. RNA hybrids were detected using subsequently mouse anti-digoxigenin $(1: 2000$, Sigma-Aldrich Chemie GmbH, Steinham, Germany), rabbit anti-mouse Ig (1:50, DAKO) and mouse alkaline phosphatase anti-alkaline phosphatase (APAAP, DAKO). The sense probe of each antisense VEGF- $A$ mRNA probe served as a

Table 2 Characteristics of used primary antibodies

\begin{tabular}{|c|c|c|c|c|c|c|c|}
\hline Antigen & Clone & Source & Directed against & $\begin{array}{l}\text { Antigen } \\
\text { retrieval }\end{array}$ & Dilution & $\begin{array}{l}\text { Incubation } \\
\text { conditions }\end{array}$ & Manufacturer \\
\hline$\alpha v \beta 6$ & $2 \mathrm{G} 2$ & Mouse & $\beta 6$ & Citrate $0.01 \mathrm{M}$ & | : 2000 & on $4^{\circ} \mathrm{C}$ & Biogen Idec, Cambridge, MA, USA \\
\hline bFGF & 6 & Mouse & bFGF & Citrate $0.01 \mathrm{M}$ & $1: 600$ & on $4^{\circ} \mathrm{C}$ & BD Biosciences, Franklin Lakes, NJ, USA \\
\hline CD31 & $\mathrm{JC} / 70 \mathrm{~A}$ & Mouse & Endothelial cells & Citrate $0.01 \mathrm{M}$ & $1: 400$ & on $\mathrm{RT}$ & Neomarkers, Fremont, CA, USA \\
\hline CD68 & KP-I & Mouse & Macrophages & Trypsin $0.1 \% \mathrm{w} / \mathrm{v}$ & $1: 1600$ & $o n^{a} R^{b}$ & Dako, Glostrup, Denmark \\
\hline CDI05 & $\mathrm{SN} 6 \mathrm{H}$ & Mouse & Endoglin & None & $\mid: 2000$ & I h RT & Dako, Glostrup, Denmark \\
\hline Fibronectin & & Goat & Fibronectin & Pepsin $0.4 \%$ w/v & $1: 1000$ & on $\mathrm{RT}$ & Sigma, St Louis, MO, USA \\
\hline MMP-2 & CA-400I & Mouse & Proform of MMP-2 & None & $\mid: 200$ & on RT & Neomarkers, Fremont, CA, USA \\
\hline VEGF-A & & Rabbit & VEGF-A & Pepsin $0.4 \%$ w/v & $1: 100$ & $2 \mathrm{~h} \mathrm{RT}$ & Santa Cruz Biotechnology Inc., Santa Cruz, CA, USA \\
\hline
\end{tabular}

bFGF = basic fibroblast growth factor; VEGF = vascular endothelial growth factor-A. ${ }^{\mathrm{a} O} \mathrm{n}=$ overnight. ${ }^{\mathrm{b}} \mathrm{RT}=$ room temperature. 
negative control. A cervical cancer sample stained for TGF- $\beta 1$ mRNA served as a positive control.

\section{Evaluation of immunohistochemical staining and RNA-in situ hybridisation}

CD68-, VEGF- and bFGF-positive cells were quantitated by counting the number of stained cells per five, randomly selected, high-power fields (HPF, $\times 400)$. CD68-positive cells at the border of the epithelial-stromal interface were counted as present or absent. CD31- and CD105-positive vessels were quantitated by first searching for a high density of vessels at low magnification $(\times 200$, the so called 'hot-spots') in the stroma, followed by counting the number of positive vessels in five of these hot-spots at high magnification (HPF, $\times 400)$ (Weidner et al, 1991). The presence of CD105-positive vessels within the epithelial cell clusters or at the epithelial-stroma interface, were counted as present or absent. Fibronectin was scored at the epithelial-stroma interface as described by Havenith et al (1988), dividing the immunoreactivity in either $<75 \%$ immunoreactivity or $>75 \%$ immunoreactivity.

The staining of $V E G F-A$ mRNA as well as VEGF-A protein, PAI-1, MMP-2 and $\alpha v \beta 6$ in the tumour cells was scored as described earlier (Ruiter et al, 1998). Intensity was scored as none (0), weak (1), moderate (2) or strong (3) at low magnification $(\times 100)$.
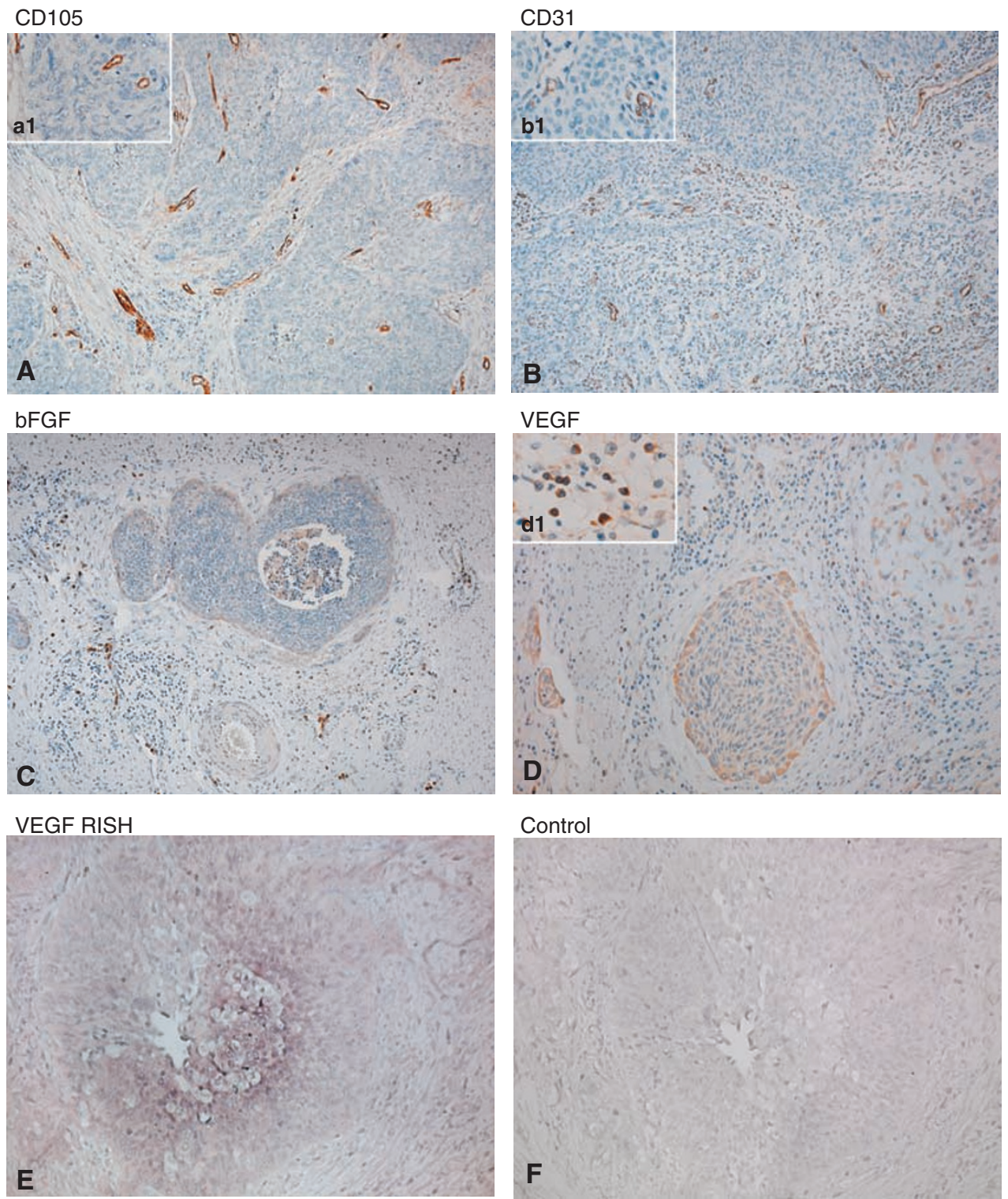

Figure I Expression and location of CDI05- and CD3I-positive vessels, bFGF, VEGF fibronectin, $\alpha \mathrm{v} \beta 6$, PAI-I and CD68-positive cells. Expression and location of CDI05- and CD3I-positive vessels, bFGF and VEGF-A were determined using immunohistochemistry as well as RNA-in situ hybridisation as described in Materials and Methods ( $\times 125$ magnification). (A) CDI05 vascular staining, Al. Detail ( $\times 400$ magnification) of vessels present in the tumour stroma as well as in the epithelial cell clusters, (B) CD3 I vascular staining, BI. Detail ( $\times 400$ magnification) of vessels present in the tumour stroma as well as in the epithelial cell clusters. (C) bFGF, positive staining of the border of the epithelial cell clusters and cells in the stromal compartment; (D) VEGF-A immunohistochemical staining with increased positive staining of the borders of the epithelial cell clusters, DI. Detail ( $\times 400$ magnification) of VEGF-Apositive stromal cells, (E) VEGF-A RNA-in situ hybridisation with weak cytoplasmic staining of the epithelial cell clusters, (F) Negative (sense) control of VEGFA RNA-in situ hybridisation. Expression and location of fibronectin, $\alpha \vee \beta 6$, PAI-I and CD68-positive cells ( $\times 400$ magnification). (G) fibronectin, positive staining (> 75\%) of the stromal compartment. $(\mathbf{H}) \alpha \vee \beta 6$, positive staining (strong intensity; of the border) of the epithelial cell clusters. (I) PAI- I, positive staining of the epithelial cell clusters. (J) Positive staining of CD68-positive cells in the stromal compartment and in the epithelial cell clusters. 
Fibronectin

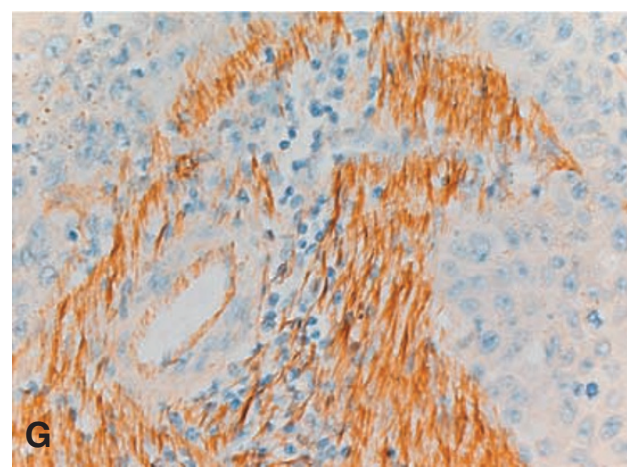

PAl-1

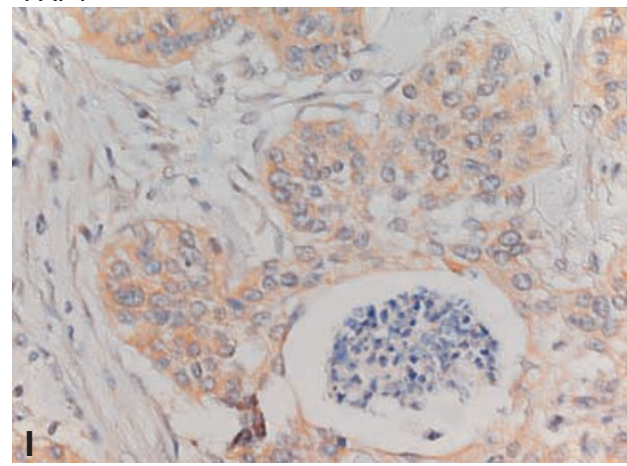

$\alpha v \beta 6$
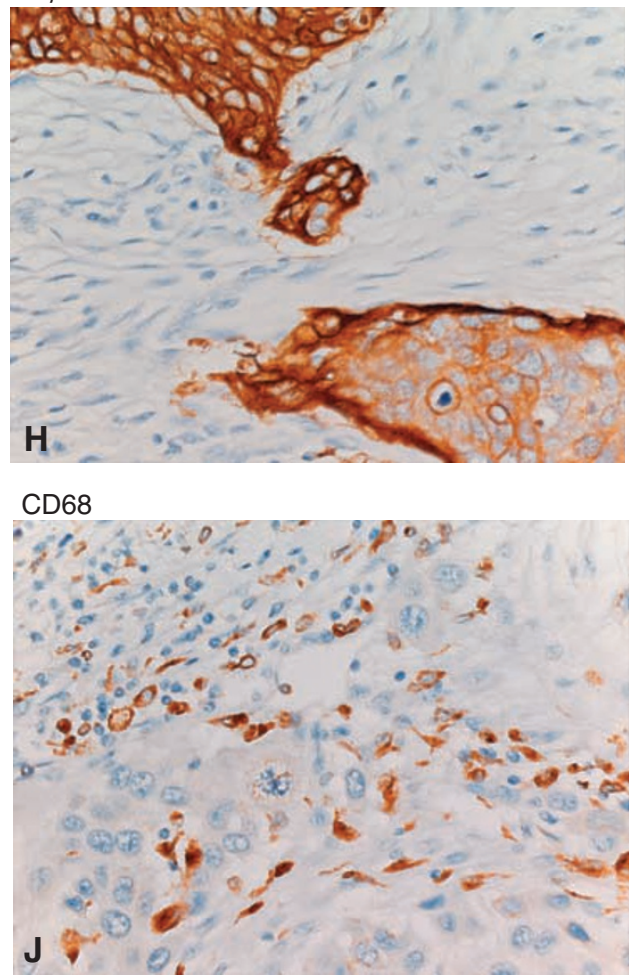

Figure I Continued.

Furthermore, the percentage of positive tumour cells was determined and divided into groups, numbered from 0 to $5: 0 \%$ (0, absent), 1-5\% (1, sporadic), 6-25\% (2, local), 26-50\% (3, occasional), $51-75 \%$ (4, majority) and $76-100 \%$ (5, large majority). The two parameters were combined, representing the sum of both the percentage and the staining intensity of the positive cells, resulting in an overall score $(0$ or $2-8)$. Owing to low expression of $V E G F-A$, the scores were combined into two groups: category 0 (score 0 , no expression), category 1 (score 2-8, expression present). Expression was scored by two independent researchers without knowing the identity and clinical outcome of patients.

\section{Statistical analysis}

Data from immunohistochemistry as well as RNA-in situ hybridisation are given as the mean \pm s.d. Statistical analysis was performed using SPSS 14.0 (SPSS Inc., Chicago, IL, USA). Data were processed by using a $\chi^{2}$-test, the Mann-Whitney $U$-test or the Fisher's exact test, depending on number and distribution of the compared groups. Kaplan-Meier survival curves were generated to assess differences in disease-free survival (defined as the observation time in months from surgery to relapse of the disease) or cumulative overall survival (defined as time in months from surgery to death owing to cervical cancer). $P<0.05$ was considered statistically significant.

\section{RESULTS}

\section{Number and location of CD105- and CD31-positive blood vessels}

First, we have investigated the relationship between the number and location of (newly formed) blood vessels, using anti-CD105 and anti-CD31 (providing an estimate of the total number of blood

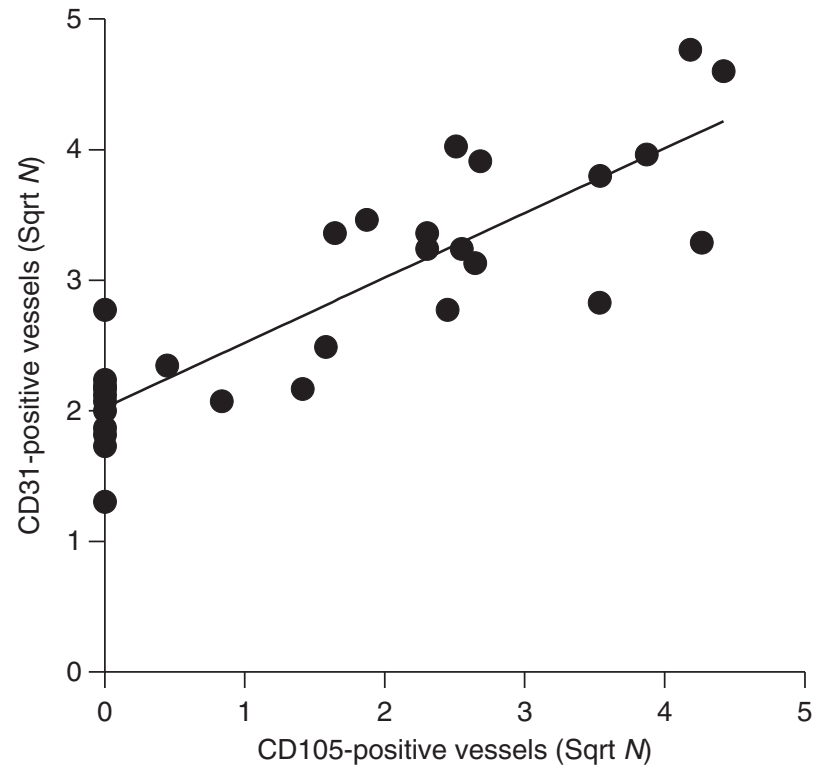

Figure 2 Correlation between CDI05- and CD3I-positive vessels. Number of stromal CDI05- and CD3I-positive vessels was determined using immunohistochemistry as described in Materials and Methods (Pearson, $r^{2}=0.747, P<0.001$ )

vessels) monoclonal antibodies (Figure $1 \mathrm{~A}$ and $\mathrm{B}$, respectively). The number of newly formed stromal CD105-positive vessels (mean $5 \pm 1$ ) was lower than the number of stromal CD31-positive vessels (mean $9 \pm 1$ ). The number of CD105-positive vessels ranged from 0 to 20, whereas the number of CD31-positive vessels ranged from 2 to 23 . In 8 out of 30 cases CD105-positive vessels were 


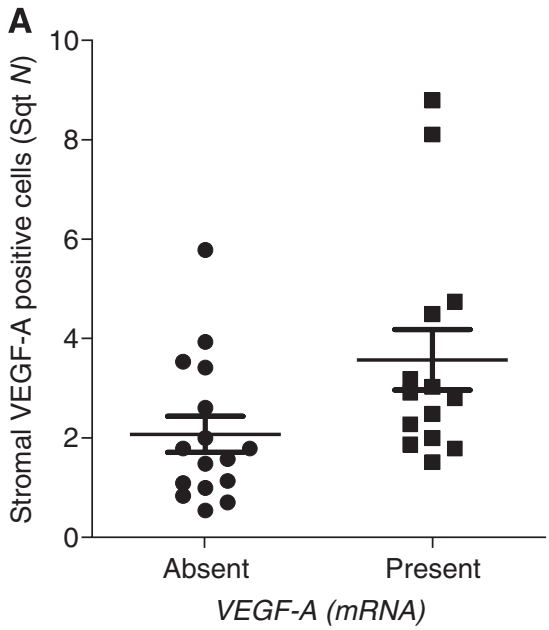

B

(mRNA)

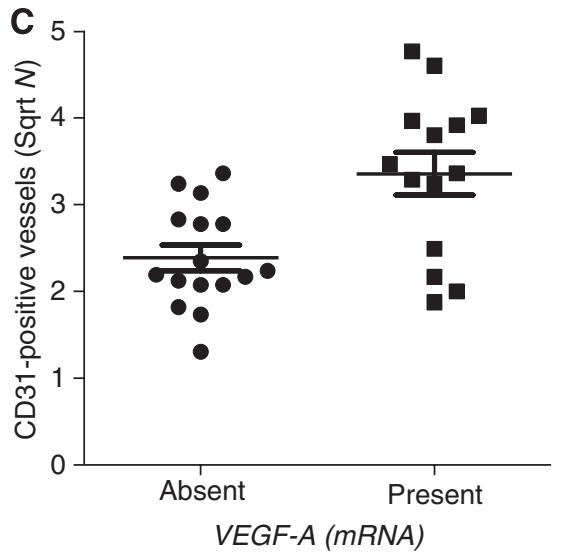

Figure 3 Association between VEGF-A (mRNA) expression measured in the epithelial cell clusters and the number of VEGF-A-positive cells and blood vessels. (A) Correlation between VEGF-A (mRNA) expression measured in the epithelial cell clusters and the number of VEGF-A-positive cells (MannWhitney U-test, $P=0.048$ ) in tumour stromal compartment. (B) Correlation between VEGF-A (mRNA) expression measured in the epithelial cell clusters and the number of stromal CDI05-positive vessels (Mann-Whitney U-test, $P=0.013$ ). (C) Correlation between VEGF-A (mRNA) expression measured in the epithelial cell clusters and the number of stromal CD3I-positive vessels (Mann-Whitney U-test, $P=0.005$ ).

located within the epithelial cell clusters, whereas in 18 out 30 cases CD31-positive vessels were observed within these clusters. There was a significant correlation between the expression of CD105- and CD31-positive vessels in the stroma $\left(r^{2}=0.747, P<0.001\right.$; Figure 2$)$.

\section{Number and location of VEGF-A and bFGF-positive cells}

Subsequently, we have investigated the number and location of bFGF- and VEGF-A-positive cells (Figure $1 \mathrm{C}$ and D, respectively). Basic fibroblast growth factor-positive cells were predominantly observed in the stroma. The number of bFGF-positive cells ranged from 0 to 71 (mean $24 \pm 5$ ). Only 3 out of 30 cases showed bFGF expression within the epithelial cell nests. These cells were mainly located at the epithelial-stromal interface. Another six tumours showed bFGF-positive cells within the necrotic centres of epithelial nests, whereas tumour cells showed a negative staining. Vascular endothelial growth factor-A was both measured at the protein level using with immunohistochemistry and at the mRNA level using RNA-in situ hybridisation (Figure 1E). Vascular endothelial growth factor-A-positive cells were mainly observed in the stroma. The number of VEGF-A-positive cells ranged from 0 to 77 (mean $11 \pm 3$ ). Weak VEGF-A protein expression was observed throughout the epithelial cell clusters with an increased intensity at the epithelial-stromal interface (16 out of 30 cases; Figure 1D). In addition, VEGF-A (mRNA) expression was observed in the epithelial cell clusters (14 out of 30 cases). Expression of VEGF-A (mRNA) within the epithelial cell clusters did not correlate with VEGF-A protein expression within the epithelial cell clusters, but did associate with the number of VEGF-A-positive cells in the stroma $(P=0.048$, Figure $3 \mathrm{~A})$.

\section{Association between blood vessels and bFGF and VEGF-A}

No significant association between the presence of CD105-positive vessels in the tumour or the total number of CD105-positive and CD31-positive vessels in the stroma, and the number of bFGF- or VEGF-A-positive cells in the stroma was observed (data not shown). However, both the number of CD105-positive and the number of CD31-positive vessels in the stroma associated significantly with expression of VEGF-A (mRNA) within the epithelial cell clusters $(P=0.013$ (Figure 3B) and $P=0.005$ (Figure 3C), respectively).

\section{Association between blood vessels and tumour-associated macrophages}

As angiogenic factors are also produced by tumour-associated macrophage (TAM), we have enumerated the number of CD68positive cells (Zijlmans et al, 2007) and correlated their number 

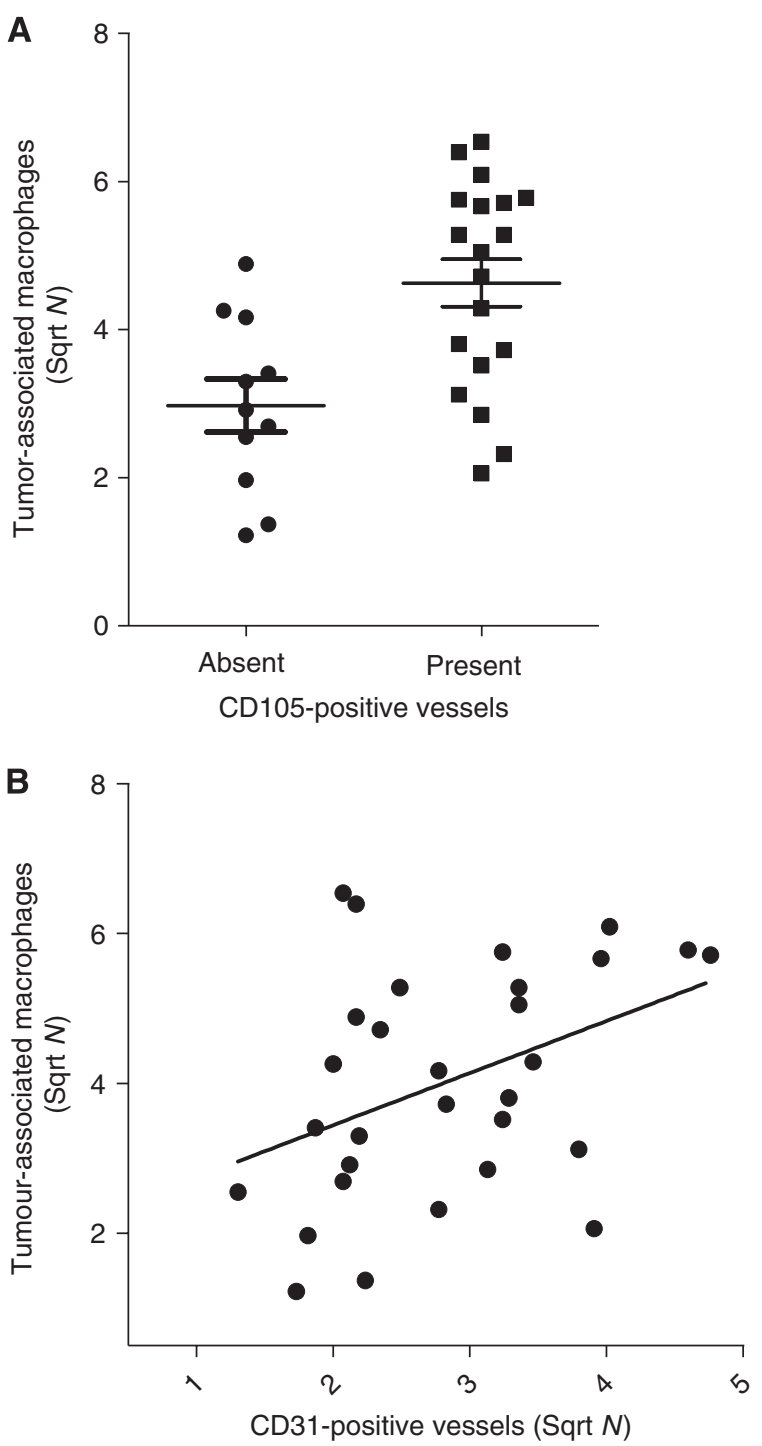

Figure 4 Association between tumour-associated macrophages and blood vessels. (A) Association between the number of total (stroma and epithelial cell clusters) tumour-associated macrophages and the presence of CDI05-positive vessels (Mann-Whitney U-test, $P=0.004$ ). (B) Correlation between the total number of tumour-associated macrophages and the number of stromal CD3I-positive vessels (Pearson, $r^{2}=0.150, P=0.034$ ).

with the number of CD105- and CD31-positive stromal vessels. The presence of CD105-positive vessels in the tumour was significantly associated with total (stroma and epithelial cell clusters) number of CD68-positive cells ( $P=0.004$; Figure $4 \mathrm{~A})$. However, the number of CD105-positive vessels in the stroma was not significantly correlated with the total number of CD68-positive cells. In addition, there was a significant correlation between the number of CD31-positive vessels in the stroma and the total number of CD68-positive cells $\left(r^{2}=0.150, P=0.034\right.$; Figure $\left.4 \mathrm{~B}\right)$.

\section{Association between blood vessels and TGF- $\beta_{1}$ target gene products PAI-1 and fibronectin and the TGF- $\beta_{1}$ activator $\alpha v \beta 6$}

To explore the role of TGF- $\beta$ in the generation of CD105-positive vessels both the presence of CD105-positive blood vessels in the epithelial cell clusters and the number of blood vessels in the stroma were associated with the presence of PAI- 1 in the epithelial cell clusters (Hazelbag et al, 2004) and the amount of fibronectin in the stroma (Hazelbag et al, 2002), both target genes of TGF- $\beta_{1}$. Neither the presence of CD105-positive vessels within the epithelial cell clusters nor the number of stromal CD105-positive vessels associated significantly with PAI-1 expression (data not shown). However, an association between the number of stromal CD31positive vessels and high levels of fibronectin $(>75 \%)$ was found $(P=0.038$; data not shown). Furthermore, a significant association between the number of stromal CD31-positive vessels and moderate or strong staining intensity ( $v s$ no or weak staining intensity at the epithelial-stromal interface) of $\alpha v \beta 6$ was observed $(P=0.006$; Figure $5 B)$. Although a difference between the number of stromal CD105-positive vessels and moderate or strong staining intensity ( $v s$ no or weak staining intensity at the epithelial-stromal interface) of $\alpha v \beta 6$ was observed (Figure 5A), this difference was not significant $(P=0.053)$. In addition, an association between the total number of TAM and $\alpha v \beta 6$ staining intensity was found $(P=0.002$; Figure 5C).

\section{Association between blood vessels and clinico-pathological parameters}

Finally, we have associated both the presence of CD105-positive blood vessels within the epithelial cell clusters and the number of stromal CD105- or CD31-positive blood vessels with the FIGO stage, lymph node metastasis, tumour size, infiltration depth, vascular space involvement, parametrial invasion, human papillomavirus (HPV) status and histology. No significant associations were found between the majority of these parameters and the presence of CD105-positive blood vessels within the epithelial cell clusters or the number of stromal blood vessels. Only the presence of CD31-positive vessels in the epithelial cell clusters associated significantly with vascular space involvement (Fisher's exact test, $P=0.021$ ).

The number of both CD105- and CD31-positive stromal vessels was significantly associated with the presence of positive lymph nodes $(P=0.005$ and $P=0.011$, respectively).

In addition, the number of CD105-positive stromal vessels was significantly associated with the number of positive lymph nodes $(P<0.001$; Figure 6A). Finally, the presence of CD105-positive vessels within the epithelial cell clusters showed a negative relationship with disease-free survival (Figure 6C; $P=0.007$ ). Sample size was too small to calculate whether or not this is an independent prognostic variable.

\section{DISCUSSION}

In this study, we have investigated the role of endoglin (CD105), a regulator of TGF- $\beta$ signalling on endothelial cells, bFGF and VEGF-A expression in 30 cervical carcinoma specimens. Most vessels were detected in the stroma as could be expected, as a preexisting vascular network is necessary for developing new vessels (Hicklin and Ellis, 2005). Only one recent study has reported on the expression of CD105 in cervical cancer (Mazibrada et al, 2008). In agreement with this study, we also observed a positive correlation between the number of (newly formed) CD105- and (total number) CD31-positive vessels. In addition, we observed both CD105- and CD31-positive vessels within the epithelial cancer cell clusters. As blood vessels originate from the vasculature in the stroma, we assume that these vessels are embedded in thin layer of stroma and surrounded by epithelial cancer cells.

Subsequently, we have assessed the association between the number of CD105-vessels and bFGF- and VEGF-A expressing cells. We did not observe an association between bFGF-expressing cells with the number of CD105 (or CD31)-positive vessels. An increase in $b F G F$ mRNA expression has been reported during cervical tumour development (Fujimoto et al, 1997; Van Trappen et al, 2002), whereas a decrease in $b F G F$ expression was reported in the 

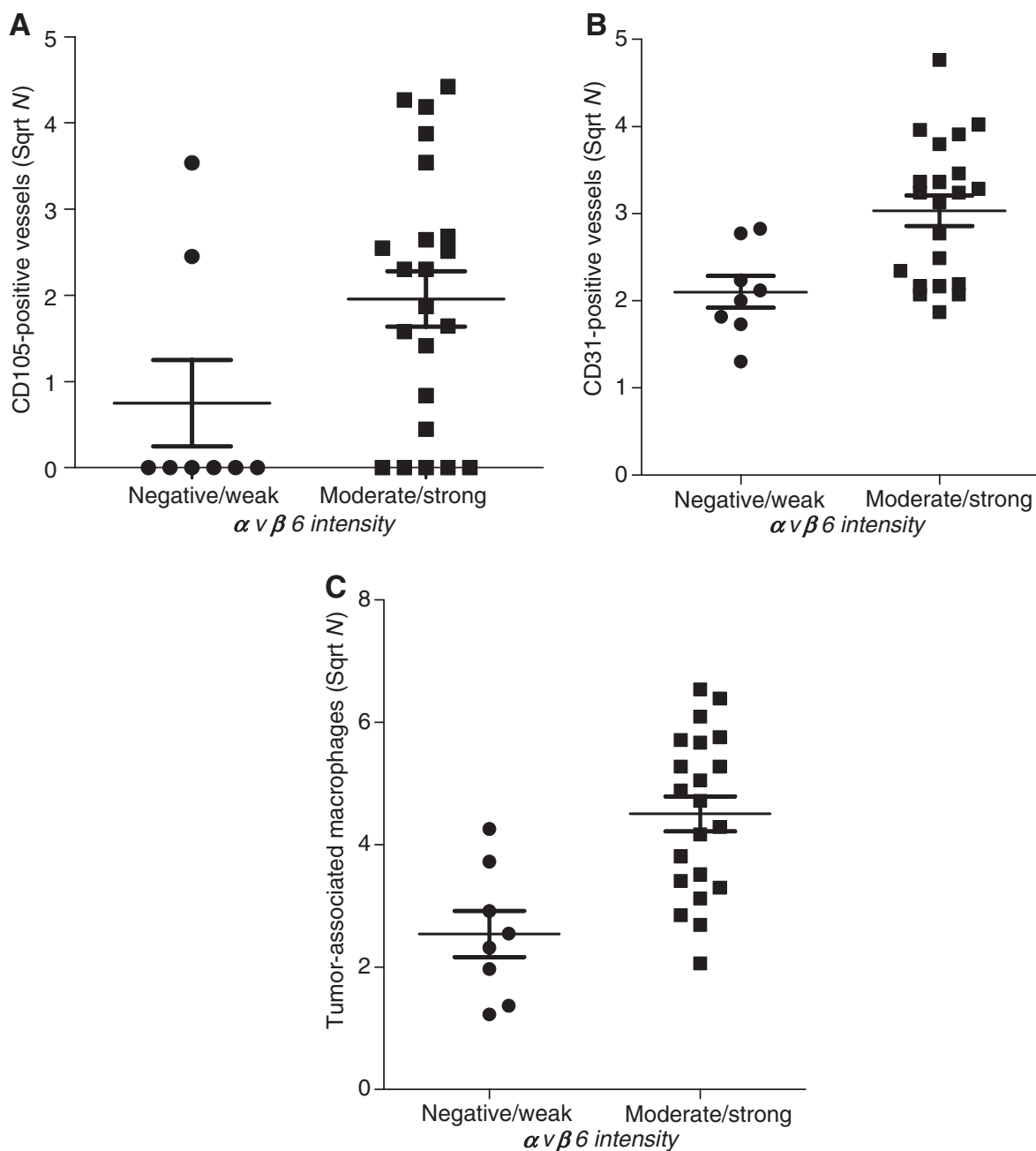

Figure 5 Association between $\alpha v \beta 6$ expression and CD3I-positive vessels and tumour-associated macrophages. (A) Association between the presence of moderate/strong $\alpha v \beta 6$ intensity and the number of stromal CDI05-positive vessels (Mann-Whitney $U$-test, $P=0.053$ ). (B) Association between the presence of moderate/strong $\alpha \vee \beta 6$ intensity and the number of stromal CD3I-positive vessels (Mann-Whitney $U$-test, $P=0.006)$. (C) Association between the presence of moderate/strong $\alpha \vee \beta 6$ intensity and the total number of tumour-associated macrophages (Mann-Whitney $U$-test, $P=0.002$ ).

study of Soufla et al (2005). To our knowledge, our study is the first study on bFGF-expressing cells in cervical carcinoma at the protein level using immunohistochemistry. Our study confirmed the absence of a statistical significant association between $b F G F$ and VEGF-A expression in cervical cancer (data not shown) as earlier shown by Van Trappen et al (2002) using PCR-analysis.

A negative association between VEGF-A protein expression and microvessel density, was reported by Tjalma et al (2000) in a study comprising 152 cervical carcinoma patients. In our study, we did not find an association between either the number of CD105 (or CD31)-positive vessels (microvessel density) and VEGF-A protein expression. In contrast to the study of Tjalma et al (2000), in our study we have also determined the presence of VEGF-A mRNA expressing cells. We were able to show a positive association between expression of VEGF-A mRNA and both CD105 expression and CD31 expression, suggesting that expression of VEGF-A mRNA is positively associated with microvessel density. The associations remained significant even after a Bonferroni's correction for multiple testing by a factor 3. The presence of $V E G F-A$ mRNA only detectable in the centre of the epithelial cell clusters, suggests that this is caused by hypoxia (Lee et al, 2008). Although VEGF-A is considered to be one of the most important factors involved in angiogenesis (Hicklin and Ellis, 2005), surprisingly VEGF-A protein present at the epithelial-stromal interface did not correlate with the number of CD105 (or CD31)positive vessels. This might be explained by consumption of VEGF-A protein by target cells.

The role of TAM in pressing an angiogenic switch has been highlighted by Lin and Pollard (2007), suggesting that TAM significantly contribute to angiogenesis. Tumour-associated macrophages are known to contain many proangiogenic factors, such as VEGF (Leek et al, 2000), TNF- $\alpha$ (Pusztai et al, 1994), CXCL-8 (Fujimoto et al, 2000), bFGF (Stupack et al, 1999) and proteases such as MMP-2 and MMP-9 (Pollard, 2004). These MMPs are able to free pro-angiogenic cytokines, such as TGF- $\beta$ and VEGF-A, from the matrix. Indeed, we could show a positive association between the presence of CD105-positive vessels in the tumour, the stromal number of CD31-positive vessels and the total number of TAM. In contrast, an earlier study by Davidson et al (1999), using CD31 as a vessel marker did not find this association. Our results suggest that that the presence of TAM is associated with neo-angiogenesis. However, there was no significant relationship between the number of VEGF-A-positive cells in stroma or VEGF-A protein in the epithelial cancer cell clusters and the number of TAM. This suggests that other factors in addition to VEGF-A contribute to angiogenesis. These factors may be induced by cytokines from TAM or liberated from the extracellular matrix by MMPs derived from TAM. In addition, we did not observe a 

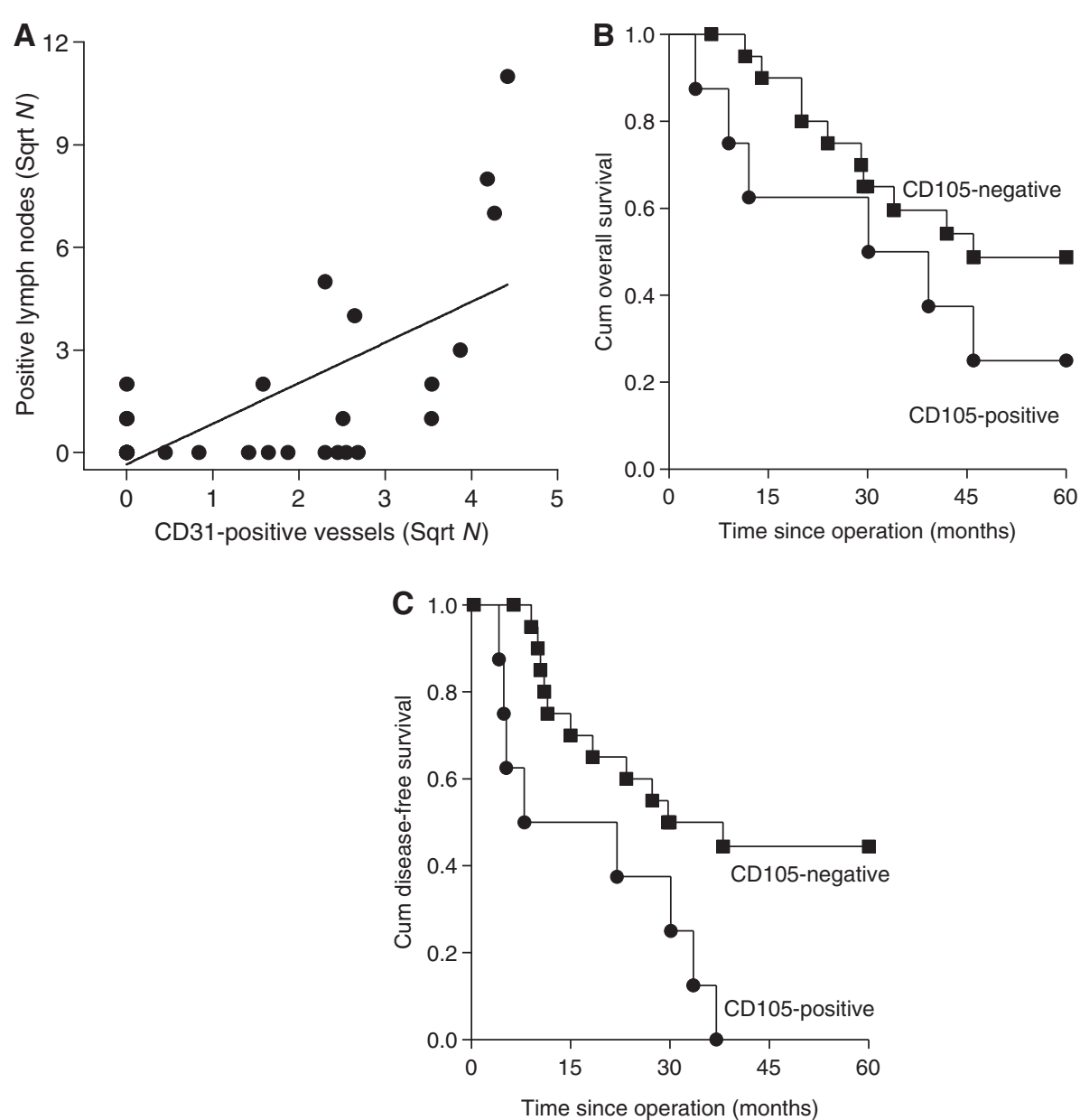

Figure 6 Association between CD I05-positive vessels, the number of positive lymph nodes and survival. (A) Correlation between the number of stromal CDI05 positive vessels and the number of positive lymph nodes $\left(r^{2}=0.615 ; P<0.001\right)$, (B) Overall survival (Kaplan-Meier, logrank I.55, $P=0.2$ I 4$)$, $(\mathbf{C})$. Disease-free survival (Kaplan-Meier, logrank 7.28, $P=0.007$ ), both stratified by presence of CDI05-positive vessels within the epithelial cell clusters of cervical carcinoma. CDI05 present in epithelial cell clusters, CDI05 absent in epithelial cell clusters.

significant association between MMP-2 expressed at the border between the epithelial cancer cells and VEGF-A protein (Sier et al, 2006).

Transforming growth factor- $\beta_{1}$ plays an important role in angiogenesis, by promoting proliferation and migration of endothelial cells or promoting vessel maturation (ten Dijke and Arthur, 2007). Furthermore, TGF- $\beta_{1}$ is known to induce VEGF expression (McMahon et al, 2006). We did not observe an association between the presence or the number of CD105-positive vessels and PAI-1, fibronectin (surrogate markers of TGF- $\beta_{1}$ activity), $\alpha v \beta 6$ and MMP-2 (activators of TGF- $\beta_{1}$ ) expression. However, the total number of (CD31-positive) vessels correlated with the expression of $\alpha v \beta 6$. In addition, $\alpha v \beta 6$ correlated significantly with the amount of fibronectin $(P=0.037$, data not shown), which is one of the factors that supports blood vessel growth (Hazelbag et al, 2007). Interestingly, $\alpha v \beta 6$ is also known to upregulate MMP-9 expression and thus may also contribute to the release of VEGF-A from the extracellular matrix (Scott et al, 2004).

On the basis of all our findings, we suggest that TGF- $\beta_{1}$ also plays a central role in the progression of cervical carcinoma (Figure 7). Latent TGF- $\beta_{1}$ is produced amongst others by cervical cancer cells, secreted and stored in the extracellular matrix. This TGF- $\beta_{1}$ is then processed by either the epithelial cell specific integrin $\alpha v \beta 6$ (Sheppard, 2005; Hazelbag et al, 2007) or by MMPs, especially active MMP-2 (Sier et al, 2006) in complex with MMP-14 and TIMP-2 on the cell membrane of cervical cancer cells at the epithelial cell-stroma border. Active TGF- $\beta_{1}$ can induce VEGF in the epithelial cancer cells and differentiates fibroblasts surrounding the epithelial cancer cells into myofibroblasts. Furthermore, active TGF- $\beta_{1}$ depending on the local concentration either promotes endothelial proliferation and migration or promotes cytostatis and vessel maturation. In addition, active TGF- $\beta_{1}$ acts as an immunosuppressor by blocking the activity of the inflammatory cells and inducing FoxP3-positive regulatory cells (Jordanova et al, 2008) and Th17 cells (Manel et al, 2008).

The prognostic value of CD105 and CD31 has been assessed earlier in breast, colon and ovarian carcinomas (Dales et al, 2004; Erdem et al, 2006; Minhajat et al, 2006; Dhakal et al, 2008). High expression of CD105 correlated with increased risk of metastasis in lymph node-positive breast carcinoma patients (Dales et al, 2004). In this latter study, CD105 was shown to have an improved predictive value compared with CD31. In agreement with this study, in cervical carcinoma we observed an association between the number of CD105-positive vessels and the number of positive lymph nodes. With respect to survival, only the presence of newly formed vessels (CD105) within the epithelial cell clusters was correlated with a poor disease-free survival. 


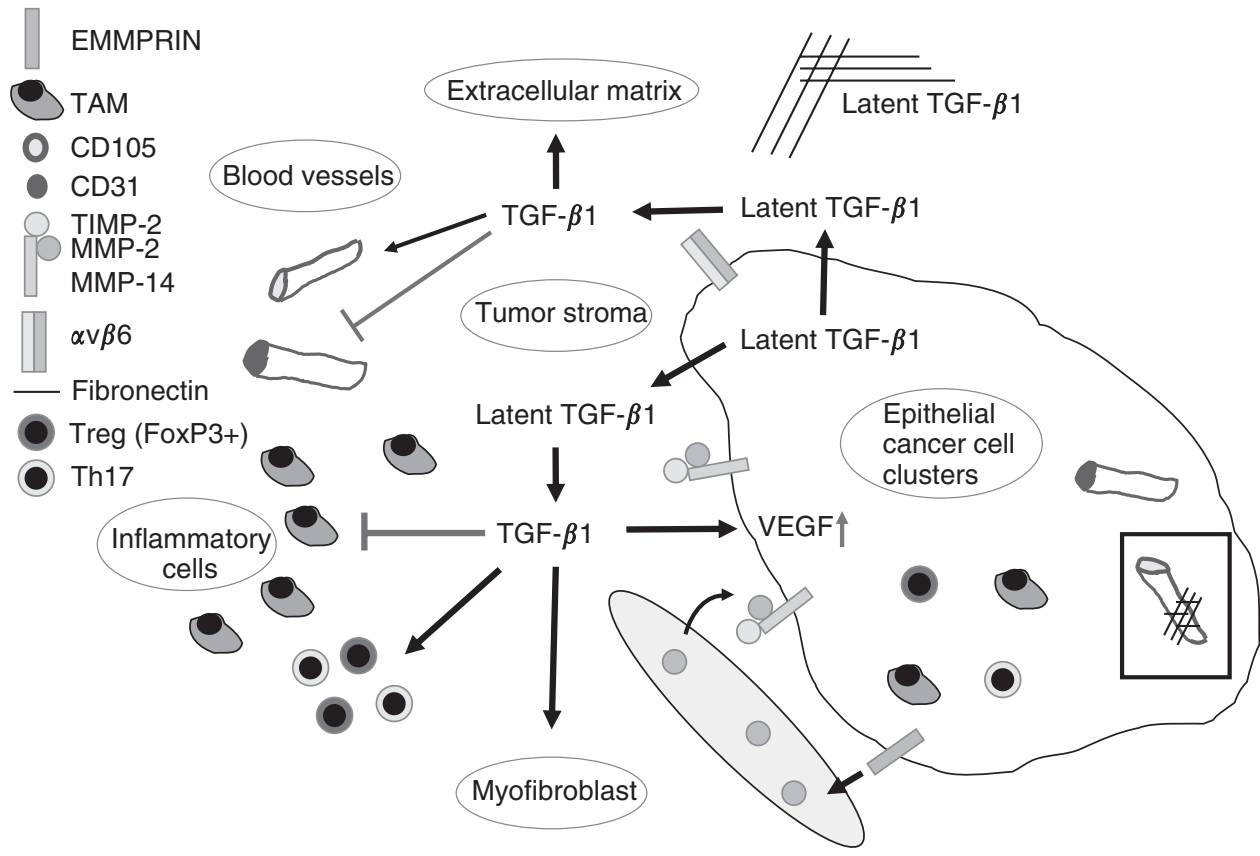

Figure 7 Role of TGF- $\beta_{1}$ in cervical cancer. Cervical tumours are composed of malignant epithelial cells, tumour stroma, comprising the tumour vasculature extracellular matrix and (myo)fibroblasts, and an inflammatory infiltrate. Latent TGF- $\beta_{1}$ is produced amongst others by cervical cancer cells, secreted and stored in the extracellular matrix. TGF- $\beta_{1}$ can be activated by the epithelial cell specific integrin $\alpha v \beta 6$ or by matrix metalloproteinases (MMPs), especially active MMP-2 in complex with MMP-I4 and TIMP-2 on the cell membrane of cervical cancer cells at the epithelial cell-stroma border. Active TGF- $\beta_{1}$ induces VEGF in the epithelial cancer cells and differentiates fibroblasts into myofibroblasts. Depending on the local concentration, active TGF- $\beta_{1}$, promotes endothelial proliferation and migration and promotes cytostatis and vessel maturation. Active TGF- $\beta_{1}$ acts as an immunosuppressor by blocking the activity of the inflammatory cells and inducing FoxP3-positive regulatory cells and ThI7 cells.

Our study suggests that the presence of CD105-positive vessels in the epithelial cell clusters may be of use as a (poor) prognostic factor in cervical carcinoma. This is important as CD105 has been proposed as a marker of tumour vasculature and a potential target for therapy of cervical carcinoma (Dallas et al, 2008).

\section{REFERENCES}

Bremnes RM, Camps C, Sirera R (2006) Angiogenesis in non-small cell lung cancer: the prognostic impact of neoangiogenesis and the cytokines VEGF and bFGF in tumours and blood. Lung Cancer 51: 143-158

Byrne AM, Bouchier-Hayes DJ, Harmey JH (2005) Angiogenic and cell survival functions of vascular endothelial growth factor (VEGF). $J$ Cell Mol Med 9: 777-794

Condeelis J, Pollard JW (2006) Macrophages: obligate partners for tumor cell migration, invasion, and metastasis. Cell 124: 263-266

Cooper RA, West CM, Wilks DP, Logue JP, Davidson SE, Roberts SA, Hunter RD (1999) Tumour vascularity is a significant prognostic factor for cervix carcinoma treated with radiotherapy: independence from tumour radiosensitivity. Br J Cancer 81: $354-358$

Cooper RA, Wilks DP, Logue JP, Davidson SE, Hunter RD, Roberts SA, West CM (1998) High tumor angiogenesis is associated with poorer survival in carcinoma of the cervix treated with radiotherapy. Clin Cancer Res 4: 2795-2800

Dales JP, Garcia S, Andrac L, Carpentier S, Ramuz O, Lavaut MN, Allasia C, Bonnier P, Charpin C (2004) Prognostic significance of angiogenesis evaluated by CD105 expression compared to CD31 in 905 breast carcinomas: correlation with long-term patient outcome. Int J Oncol 24: $1197-1204$

Dallas NA, Samuel S, Xia L, Fan F, Gray MJ, Lim SJ, Ellis LM (2008) Endoglin (CD105): a marker of tumor vasculature and potential target for therapy. Clin Cancer Res 14: $1931-1937$

Davidson B, Goldberg I, Gotlieb WH, Lerner-Geva L, Ben Baruch G, Agulansky L, Novikov I, Kopolovic J (1999) Macrophage infiltration and

\section{ACKNOWLEDGEMENTS}

We thank Dr JJ Houwing for her help with the statistical analysis of the data. angiogenesis in cervical squamous cell carcinoma-clinicopathologic correlation. Acta Obstet Gynecol Scand 78: 240-244

Dhakal HP, Naume B, Synnestvedt M, Borgen E, Kaaresen R, Schlichting E, Wiedswang G, Bassarova A, Giercksky KE, Nesland JM (2008) Vascularization in primary breast carcinomas: its prognostic significance and relationship with tumor cell dissemination. Clin Cancer Res 14: $2341-2350$

Elliott RL, Blobe GC (2005) Role of transforming growth factor beta in human cancer. J Clin Oncol 23: 2078-2093

Erdem O, Taskiran C, Onan MA, Erdem M, Guner H, Ataoglu O (2006) CD105 expression is an independent predictor of survival in patients with endometrial cancer. Gynecol Oncol 103: $1007-1011$

Fujimoto J, Ichigo S, Hori M, Hirose R, Sakaguchi H, Tamaya T (1997) Expression of basic fibroblast growth factor and its mRNA in advanced uterine cervical cancers. Cancer Lett 111: $21-26$

Fujimoto J, Sakaguchi H, Aoki I, Tamaya T (2000) Clinical implications of expression of interleukin 8 related to angiogenesis in uterine cervical cancers. Cancer Res 60: $2632-2635$

Havenith MG, Arends JW, Simon R, Volovics A, Wiggers T, Bosman FT (1988) Type IV collagen immunoreactivity in colorectal cancer. Prognostic value of basement membrane deposition. Cancer 62: $2207-2211$

Hazelbag S, Gorter A, Kenter GG, van den Broek L, Fleuren G (2002) Transforming growth factor-betal induces tumor stroma and reduces tumor infiltrate in cervical cancer. Hum Pathol 33: 1193-1199 
Hazelbag S, Kenter G, Gorter A, Dreef E, Koopman L, Violette S, Weinreb P, Fleuren $G$ (2007) Overexpression of the alphavbeta6 integrin in cervical squamous cell carcinoma is a prognostic factor for decreased survival. J Pathol 212: $316-324$

Hazelbag S, Kenter GG, Gorter A, Fleuren GJ (2004) Prognostic relevance of TGF-beta1 and PAI-1 in cervical cancer. Int J Cancer 112: 1020-1028

Hellebrekers BW, Zwinderman AH, Kenter GG, Peters AA, Snijders-Keilholz A, Graziosi GC, Fleuren GJ, Trimbos JB (1999) Surgically-treated early cervical cancer: prognostic factors and the significance of depth of tumor invasion. Int J Gynecol Cancer 9: 212-219

Hicklin DJ, Ellis LM (2005) Role of the vascular endothelial growth factor pathway in tumor growth and angiogenesis. J Clin Oncol 23: 1011-1027

Jordanova ES, Gorter A, Ayachi O, Prins F, Durrant LG, Kenter GG, van der Burg SH, Fleuren GJ (2008) Human leukocyte antigen class I, MHC class I chain-related molecule $\mathrm{A}$, and $\mathrm{CD} 8+/$ regulatory $\mathrm{T}$-cell ratio: which variable determines survival of cervical cancer patients? Clin Cancer Res 14: $2028-2035$

Lee WY, Huang SC, Hsu KF, Tzeng CC, Shen WL (2008) Roles for hypoxiaregulated genes during cervical carcinogenesis: somatic evolution during the hypoxia-glycolysis-acidosis sequence. Gynecol Oncol 108: $377-384$

Leek RD, Hunt NC, Landers RJ, Lewis CE, Royds JA, Harris AL (2000) Macrophage infiltration is associated with VEGF and EGFR expression in breast cancer. J Pathol 190: 430-436

Lin EY, Pollard JW (2007) Tumor-associated macrophages press the angiogenic switch in breast cancer. Cancer Res 67: 5064-5066

Manel N, Unutmaz D, Littman DR (2008) The differentiation of human $\mathrm{T}(\mathrm{H})-17$ cells requires transforming growth factor-beta and induction of the nuclear receptor RORgammat. Nat Immunol 9: 641 - 649

Mazibrada J, Ritta M, Mondini M, De Andrea M, Azzimonti B, Borgogna C, Ciotti M, Orlando A, Surico N, Chiusa L, Landolfo S, Gariglio M (2008) Interaction between inflammation and angiogenesis during different stages of cervical carcinogenesis. Gynecol Oncol 108: 112-120

McMahon S, Charbonneau M, Grandmont S, Richard DE, Dubois CM (2006) Transforming growth factor betal induces hypoxia-inducible factor-1 stabilization through selective inhibition of PHD2 expression. J Biol Chem 281: 24171-24181

Minhajat R, Mori D, Yamasaki F, Sugita Y, Satoh T, Tokunaga O (2006) Endoglin (CD105) expression in angiogenesis of colon cancer: analysis using tissue microarrays and comparison with other endothelial markers. Virchows Arch 448: $127-134$

Moore DH (2006) Cervical cancer. Obstet Gynecol 107: $1152-1161$

Parkin DM, Bray F, Ferlay J, Pisani P (2005) Global cancer statistics, 2002. CA Cancer J Clin 55: 74-108

Pilch H, Gunzel S, Schaffer U, Tanner B, Brockerhoff P, Maeurer M, Hockel M, Hommel G, Knapstein PG (2001a) The presence of HPV DNA in cervical cancer: correlation with clinico-pathologic parameters and prognostic significance: 10 years experience at the Department of Obstetrics and Gynecology of the Mainz University. Int J Gynecol Cancer 11: $39-48$

Pilch H, Schlenger K, Steiner E, Brockerhoff P, Knapstein P, Vaupel P (2001b) Hypoxia-stimulated expression of angiogenic growth factors in cervical cancer cells and cervical cancer-derived fibroblasts. Int J Gynecol Cancer 11: 137 - 142

Pollard JW (2004) Tumour-educated macrophages promote tumour progression and metastasis. Nat Rev Cancer 4: 71-78
Pusztai L, Clover LM, Cooper K, Starkey PM, Lewis CE, McGee JO (1994) Expression of tumour necrosis factor alpha and its receptors in carcinoma of the breast. Br J Cancer 70: 289-292

Ruiter DJ, Ferrier CM, van Muijen GN, Henzen-Logmans SC, Kennedy S, Kramer MD, Nielsen BS, Schmitt M (1998) Quality control of immunohistochemical evaluation of tumour-associated plasminogen activators and related components. European BIOMED-1 concerted action on clinical relevance of proteases in tumour invasion and metastasis. Eur J Cancer 34: 1334-1340

Salgado R, Benoy I, Vermeulen P, Van Dam P, Van Marck E, Dirix L (2004) Circulating basic fibroblast growth factor is partly derived from the tumour in patients with colon, cervical and ovarian cancer. Angiogenesis 7: $29-32$

Scott KA, Arnott CH, Robinson SC, Moore RJ, Thompson RG, Marshall JF, Balkwill FR (2004) TNF-alpha regulates epithelial expression of MMP-9 and integrin alphavbeta6 during tumour promotion. A role for TNF-alpha in keratinocyte migration? Oncogene 23: $6954-6966$

Sheppard D (2005) Integrin-mediated activation of latent transforming growth factor beta. Cancer Metastasis Rev 24: 395-402

Sier CF, Zuidwijk K, Zijlmans HJ, Hanemaaijer R, Mulder-Stapel AA, Prins FA, Dreef EJ, Kenter GG, Fleuren GJ, Gorter A (2006) EMMPRIN-induced MMP-2 activation cascade in human cervical squamous cell carcinoma. Int J Cancer 118: 2991 - 2998

Soufla G, Sifakis S, Baritaki S, Zafiropoulos A, Koumantakis E, Spandidos DA (2005) VEGF, FGF2, TGFB1 and TGFBR1 mRNA expression levels correlate with the malignant transformation of the uterine cervix. Cancer Lett 221: $105-118$

Stupack DG, Storgard CM, Cheresh DA (1999) A role for angiogenesis in rheumatoid arthritis. Braz J Med Biol Res 32: 573-581

ten Dijke P, Arthur HM (2007) Extracellular control of TGF beta signalling in vascular development and disease. Nat Rev Mol Cell Biol 8: 857-869

ten Dijke P, Goumans MJ, Pardali E (2008) Endoglin in angiogenesis and vascular diseases. Angiogenesis 11: 79-89

Tjalma W, Weyler J, Weyn B, Van Marck E, Van Daele A, Van Dam P, Goovaerts G, Buytaert P (2000) The association between vascular endothelial growth factor, microvessel density and clinicopathological features in invasive cervical cancer. Eur J Obstet Gynecol Reprod Biol 92: $251-257$

Van Trappen PO, Ryan A, Carroll M, Lecoeur C, Goff L, Gyselman VG, Young BD, Lowe DG, Pepper MS, Shepherd JH, Jacobs IJ (2002) A model for co-expression pattern analysis of genes implicated in angiogenesis and tumour cell invasion in cervical cancer. Br J Cancer 87: $537-544$

Weidner N, Semple JP, Welch WR, Folkman J (1991) Tumor angiogenesis and metastasis-correlation in invasive breast carcinoma. $N$ Engl J Med 324: $1-8$

Zijlmans HJ, Fleuren GJ, Baelde HJ, Eilers PH, Kenter GG, Gorter A (2006) The absence of CCL2 expression in cervical carcinoma is associated with increased survival and loss of heterozygosity at 17q11.2. J Pathol 208: $507-517$

Zijlmans HJ, Fleuren GJ, Baelde HJ, Eilers PH, Kenter GG, Gorter A (2007) Role of tumor-derived proinflammatory cytokines GM-CSF, TNF-alpha, and IL-12 in the migration and differentiation of antigen-presenting cells in cervical carcinoma. Cancer 109: 556-565 